\section{Wrong on animal rights}

SIR - Barbara Culliton's article on the animal rights threat to research carries the provocative headline "Can reason defeat unreason?" (Nature 351, 517; 1991).

I am constantly amazed at how wrong and even irrational some parts of the scientific establishment can be when it comes to addressing the animal rights argument. Far from adopting rational argument, the research establishment first dismissed the new philosophy as an unrealistic if not crazy message from a group of sentimental misanthropes. By so doing, they grossly underestimated the rational basis of the animal liberation arguments (for example, that developed by Peter Singer or Tom Regan), the strength of public uneasiness about what went on in research laboratories and the Dr Jekyll and Mr Hyde view of science lurking underneath the public's legitimate enjoyment of new health technologies and the latest electronic wizardry.

In the past few years, some major research organizations in the United States have decided that the animal rights community (especially People for the Ethical Treatment of Animals) need to be put back in their proper place (that is, on the fringes of American society). As a result, they have started to tout the benefits of animal research much more aggressively, using high-profile spokespersons such as Michael DeBakey and former Surgeon General Everett Koop. Also, they have portrayed 'animal rights' activists as fringe types who endanger American health standards. In taking these initiatives, their public material has increasingly accentuated appeals to emotion rather than reason in an attempt to counteract the perceived advantage of the animal protection literature. Ironically, the animal activists have been

\section{Is God careless?}

SIR - As one who accepts both darwinian evolution and orthodox Christianity, I generally appreciated David Hull's review of Darwin on Trial (Nature 352, $485 ; 1991$ ). I disagree, however, with his statement that the "God of the Galápagos is careless, wasteful, indifferent, almost diabolical." Must the Creator's characteristics be so simply and directly related to the characteristics of natural processes? The assumption of such a relationship has led to unfounded views of the Universe (for example, as a fair and efficient welfare system) and to unfounded views of God. Neither the Bible as a whole nor the Christ portrayed therein makes such an assumption.

Hull is absolutely correct that scien- trying to recast their material to appeal more to reason (including more 'scientific' analyses and more quotations from establishment figures).

While the more aggressive approach of the research establishment will probably have some impact, the arguments and the material miss the mark. First, the US animal protection community has grown from around 2 million to 10 million members in the past ten years. Even though this may represent less than 10 per cent of the adult American population, it shows that there is growing concern about animals. Second, the public accepts the need to use animals in research, so this point does not need emphasizing.

Third, the public is uneasy about the perceived treatment of animals in laboratories and consequent animal suffering. Scientists can most effectively address these concerns by presenting themselves as being equally worried about the moral issues and about addressing the needs of the animals in captivity. To do this, scientists have to accentuate the 'petlike' nature of laboratory animals (naming them, dealing with exercise and companionship needs and so on) rather than talking of scientifically sound standards of nutrition and the best animal care programme that money can buy. In other words, a scientist must break the standard public stereotype of being a dispassionate, objective and relentless seeker of the truth. Such individuals are respected but are not loved and they are certainly not perceived as good or reliable caregivers.

Recently, a research veterinarian who cares for several hundred chimpanzees, including chimpanzees in AIDS studies, was portrayed on American television as a kindly family physician for the animals.

tists have no choice but to pursue naturalistic explanations for the living world, and scientific explanations can be constructed only from some mixture of random and deterministic processes. Some version of darwinian evolution is currently the only rational scientific explanation for biological life. Darwinian evolution may be an essential component of the atheist's world view, but it is not thereby excluded from the Christian's world view. Pain, evil and the apparent capriciousness of life were acknowledged long before Darwin, and of course the Bible addresses these problems.

Department of Biology,

Charles F. AusterberRy

Creighton University,

California Street at 24th,

Omaha, Nebraska 68178, USA
He was shown admiring and tenderly handling a baby macaque. On camera, he said that he would not hire people who said they were not, at least, "bothered" by doing research on animals. On being assured that he was sincere, animal activists said that it would be difficult to criticize studies carried out by such an individual.

The research community is right that their message needs to be imbued with more emotion but they are wrong in thinking that they simply have to show more sick or cured children. Spokespersons have to become much more empathetic as regards the animals they use and show such human characteristics as partiality and emotion in speaking not only of sick humans who need cures but also suffering animals which sometimes help to provide those cures.

Finally, attacking the animal rights message and the messengers is likely to backfire in a country where 80 per cent of the public say that animals have at least some rights - even it this does not include the right not to be killed and eaten.

Tufts University,

ANDREW N. ROWAN

Center for Animals and Public Policy,

200 Westboro Road,

North Grafton,

Massachusetts 01536, USA

\section{Eye-wash}

SIR - In a News and Views article (Nature 352, 669; 1991), I was quoted as saying at a recent meeting that studying perception by recording from single cells in the central nervous system (CNS) was as misguided as searching for the essence of art in the Louvre.

This is not what I said and not what I believe. Although the Louvre may be a bit over-represented in eighteenth century French painting, it is nevertheless as good a place to seek the essence of art as any I know. Moreover, recording from single cells has taught us a great deal about how the brain functions.

What I actually said was quite different. In an attempt to explain to my more behaviourally orientated colleagues the importance of cellular neuroscience, I said that the study of single cells was the essential foundation for understanding the CNS: for the cognitive scientist, a bit like the men's room of the Louvre, taken for granted but necessary when you need it.

UCLA School of Medicine,

GORDON FAIN

Jules Stein Eye Institute,

Los Angeles,

California 90024, USA

The error was made in the Nature office. - Editor, Nature. 